\title{
IMPACT OF ADDING SEROTONIN, TRYPTOPHAN AND OPTIFEED IN DRINKING WATER ON BROILER BEHAVIOR, PERFORMANCES GROWTH AND SOME BIOCHEMICAL TRAITS OF BLOOD
}

\author{
Mahbuba A. Mustafa ${ }^{1} \quad$ Rand R. Mohammed ${ }^{2}$ \\ ${ }^{1,2}$ Animal resources Dept./ College of Agricultural Engineering Sciences/Salahaddin \\ University-Erbil/Iraq \\ Email: mahbuba.mustafa@ su.edu.krd
}

\begin{abstract}
The present study was conducted to study the impact of serotonin, tryptophan and Optifeed adding in drinking water on behavior characterize, body performance, sensory evaluation of breast and thigh meat, some biochemical parameters of blood and immune status against some diseases by ELISA of broiler (Ross-308). 400 unsexed chicks one day old were randomly distributed into 4 treatments and 4 replicates for each treatment, are: T0 (control standard drinking water DW), T1 (0.5 g tryptophan/1 L DW, T2 (2 mg serotonin/1 L DW, T3 (0.5 g Optifeed®/1 L DW). The birds were reared for 42 days and behavior traits of birds controlled by erected cameras upon all replicates. The analyzed results were significantly improved behavioral characteristics, body performance (body weight and gain, feed intake, FCR, water consumption, uniformity, liver, and gizzard\%), feasibility (economic profit), sensory evaluation (aroma, taste, tenderness, juiciness, and acceptance) of cocked breast and thigh meat, blood serum concentrations (total protein, globulin, highdensity lipoprotein (HDL), serotonin, thyroxin (T4), tryptophan), and immunological ELISA titers against Newcastle, Gumboro, and Infectious bronchitis viral diseases. Otherwise, significantly decreased mortality, and blood serum concentrations, (triglyceride, low-density lipoprotein (LDL), and corticosterone) in all treatments of water additives compared with the control. The addition of Optifeed ${ }^{\circledR}$ and serotonin positively affects in all experimental characteristics than others especially improved behavioral characterize of broiler during the rearing periods.
\end{abstract}

Keywords: serotonin precursor, broiler behavior, body performances, biochemical of blood.

Received: $5 / 11 / 2020$, Accepted: 23/12/2020

\section{INTRODUCTION}

Poultry stock behavior plays an important role in maximizing production efficiency to the unit manager and production efficiency of birds maintained, also to minimize the action of what is often uninformed debate. Behavior is the way that animals react to different stimuli they encounter in their environment, the stimuli may be from other birds, their environment, people, or another events that happen (Poultry Hub., 2019). Poultry farms are an important contributor to the human food chain, worldwide, humankind keeps an enormous number of broiler chicken for meat providing a rich source of protein and low fat (Abdoli, et al, 2018).

*Part of M.Sc. thesis submitted by the second author. 
Nowadays many neurotransmitters participant in the regulation of food consumption have been identified; among them serotonin which is also known 5-hydroxytryptamine (5-HT), it appears to have an important role in the central control of feeding behavior in both mammals and avian species. It has been noticed the deprivation of food for $24 \mathrm{~h}$ injections of 5-HT intra cerebroventricularly (ICV) in Leghorn chickens caused a significant decline in food intake (Zendehdel et al., 2012 a, b). The serotonin affection dependent on signaling to target cells, via receptors located in the gut and brain tissues, naturally serotonin occurring by essential amino acid tryptophan, It's the precursor for neurotransmitters, which are chemicals that transmit a nerve impulse across neuronal gaps that are called synapses. One of the neurotransmitters is serotonin mainly which supports feelings of well-being primarily by regulates mood, appetite, sleep cycles (Aliouche. 2018), locomotion (Uçeyler et al., 2010), feeding (Lam et al., 2010). Because tryptophan is a precursor of serotonin, it stands out for involvement in protein synthesis, which is related to the stimulation of feed intake. Tryptophan is an essential amino acid, requires in many organs in the body. When consumed tryptophan, the body absorbs it and changes it to eventually become a hormone called serotonin. Tryptophan also is found to influence the behavioral status of birds by producing two hormones; serotonin and melatonin (Emadi et al., 2010). Fernstrom (2013) display the synthesis of serotonin from tryptophan derives from a two-step process, the rate of serotonin synthesis dependent on tryptophan concentrations in the brain. However the level of tryptophan in blood affected by dietary factors, and other amino acids can modify tryptophan uptake in the brain, additionally the amount of serotonin formation (Soh and Walter, 2011). Optifeed as feed additives which composed of medicinal herbs, aromatic plants, essential oils, and spices (Mustafa et al., 2019; Ali and Al-Bandar, 2019), although consisting of a mixture of plant extracts (thyme, peppers, turmeric, cinnamon) and soaps as well as vitamin $\mathrm{E}$ and natural flavoring agents. Also, poultry phasing several problems during growth period like to stress which affects on the broiler growth, performance, and behaviors so to reduce this detrimental effect many researchers turned to use. optifeed additives to increase broiler appetites and stimulate production performance. stimulate the center of appetite in the brain via smell and taste and depressing the stress because it has a good smell and special taste which is a good indicator for growth because increased appetite promotes the feed consumption, stimulates the digestion process, enhances immunity and as natural antioxidants (Fode, 2013).

This study aimed to know the best additive in drinking water of broiler chicks on their behavior and growth performance, economic profit, meat sensory, immune statue and blood biochemical concentrations especially serotonin which well-being the mood, and behavior of birds.

\section{MATERIAL AND METHOS}

This study was conducted at Poultry house/ Animal resources Dept./ College of Agricultural Engineering Sci/ Salahaddin University-Erbil/ Iraq. 400 unsexed, one-day old broiler chicks (Ross-308) were brought from Taqtaq hatchery and reared in floor pens of identical size $(2 \times 1.25 \mathrm{~m})$, it is ground covered with wood shaves. The drinkers and a 
feeders were hanged in the center of pen, so that broilers could drink or eat from any part of the pen. The birds were distributed randomly in four groups and three replicates each as follows: T0 (Control: drinking water without adding-DW), T1: (0.5 g tryptophan/1 L DW), T2 (2 mg serotonin/1 L DW, T3 (0.5 g Optifeed®/1 L DW). Feed and water were ad libitum submitted. The experimental rations were produced in Kosar company, contains starter (110), grower (11-25), finisher (26-42) days: $3000,3100,3175 \mathrm{kcal} / \mathrm{kg}$ metabolizable energy and 23, 21, $20 \%$ crude protein respectively. Chicks received $24 \mathrm{~h}$ light during $1^{\text {st }} \mathrm{wk}$ then gradually decreased to 20 L:4 D schedule. Cameras were erected (about 16 cameras) in all replicates of treatments to control and observe poultry behavior throughout $24 \mathrm{~h}$ a day. Also, birds were vaccinated against Gumboro at 7 and 14 days and Newcastle at 10 and 20 days of rearing. Behavior observation determined eating and drinking at set and up position, walking, immobility, wing flapping, preening, pecking, feather pecking, and aggressiveness of birds.

The birds from each replicate was randomly selected to measuring body weight, and gain, feed intake and FCR, water consumption, mortality, liver and gizzard relative weights, uniformity\%, production index (PI), feasibility or economic profit were calculated. As based in the method of Hugo et al., (2009), at the end of study six samples of thigh and breast meat from each treatment were chilled in $\left(4^{\circ} \mathrm{C}\right)$ and frozen at $\left(-20^{\circ} \mathrm{C}\right)$ for 7 days before sensory analyses, the samples of meat were prepared, then served to the sensory tests. Hedonic scale ( 1 to 7 ) was used for aroma, taste, tenderness, juiciness, and acceptance analysis.

At the end of the study ( $42 \mathrm{~d}$ ) blood samples were collected from the brachial vein of 15 birds of each group using EDTA tubes for counting heterophil and lymphocyte with Wright-Giemsa stains to determine the H/L ratio. Serum separated from collected blood and determined total protein, globulin, HDL, LDL, triglyceride, tryptophan, thyroxin, corticosterone, serotonin concentrations and antibodies titers against Gamboro, Newcastle, Infectious bronchitis viral diseases were measured by ELISA according to the instructions of the kits included in the Buyer's Guide for Life Science Bio-compare.

All data were analyzed using CRD (Completely Randomized Design) by the SAS institute program (SAS, 2005). Duncan's multiple range tests were used to compare differences among the treatments.

\section{RESULTS AND DISCUSSION}

Table 1 presents the data of the analysis of the impact of adding tryptophan, serotonin, and Optifeed ${ }^{\circledR}$ in drinking water on broiler behavior characteristics comparisons with control which was used normal water at 42 days. Broiler chickens reared in treatments when were significant $(\mathrm{P}<0.01)$ increased eating when the birds at up position and dust bathing main $\mathrm{T} 3$ higher than $\mathrm{T} 2$ and $\mathrm{T} 1$ in water additive groups in comparison to control $\mathrm{T} 0$, also at $(\mathrm{P}<0,05)$ increased walking, wing flapping and preening $\mathrm{T} 1, \mathrm{~T} 2$ and $\mathrm{T} 3$ respectively while the immobility higher in $\mathrm{T} 1$ and $\mathrm{T} 2$. However, there were insignificant differences among treatments in drinking at set position and pecking. Otherwise, significantly $(\mathrm{P}<0,05)$ decreased eating at set position especially $\mathrm{T} 3$ reduced higher than $\mathrm{T} 2$ and T1, although drinking at up position, feather pecking and aggressiveness were 
significantly $(\mathrm{P}<0.01)$ reduced in water additive groups compare with control. The improvement of broiler behavior may be related to increasing of serotonin concentration in the additive treatments, which is explained by Natalie (2018), serotonin a neurotransmitter it contains an essential amino acid "tryptophan" can help the body to produce more serotonin which chemically effects on the brain by improving mood, eating foods, improving overall health and wellbeing associates it with positive mood, and impact on the central nervous system, also it plays a role in the modulation of behavioral and physiological processes, so it's used as an indicator to evaluate alterations in behavioral adaptation and reproduction.

Table (1): The impact of adding tryptophan, serotonin, and Optifeed® in drinking water on broiler behavior characteristics at 42 days.

\begin{tabular}{|cc|c|c|c|c|c|c|}
\hline Traits & $\mathrm{T} 0$ & $\mathrm{~T} 1$ & $\mathrm{~T} 2$ & $\mathrm{~T} 3$ & $\mathrm{MSE}$ & S.L \\
\hline Eating \% & Set & $6.13^{\mathrm{a}}$ & $5.43^{\mathrm{ab}}$ & $5.47^{\mathrm{ab}}$ & $4.43^{\mathrm{b}}$ & 0.33 & $*$ \\
& $\mathrm{Up}$ & $11.03^{\mathrm{c}}$ & $12.43^{\mathrm{b}}$ & $12.23^{\mathrm{b}}$ & $15.40^{\mathrm{a}}$ & 0.65 & $* *$ \\
\hline Drinking \% & Set & $3.87^{\mathrm{a}}$ & $3.90^{\mathrm{a}}$ & $3.53^{\mathrm{a}}$ & $3.10^{\mathrm{a}}$ & 0.18 & N.S \\
& $\mathrm{Up}$ & $19.80^{\mathrm{a}}$ & $18.37^{\mathrm{b}}$ & $15.77^{\mathrm{c}}$ & $16.60^{\mathrm{c}}$ & 0.90 & $* *$ \\
\hline Walking \% & $6.93^{\mathrm{b}}$ & $7.57^{\mathrm{ab}}$ & $8.83^{\mathrm{a}}$ & $8.67^{\mathrm{a}}$ & 0.41 & $*$ \\
\hline Immobility \% & $21.57^{\mathrm{b}}$ & $24.33^{\mathrm{a}}$ & $21.54^{\mathrm{b}}$ & $20.67^{\mathrm{b}}$ & 1.31 & $*$ \\
\hline Wing flapping \% & $3.40^{\mathrm{b}}$ & $3.90^{\mathrm{b}}$ & $5.06^{\mathrm{a}}$ & $5.40^{\mathrm{a}}$ & 0.21 & $*$ \\
\hline Dust bathing \% & $3.60^{\mathrm{c}}$ & $4.17^{\mathrm{b}}$ & $6.37^{\mathrm{ab}}$ & $7.67^{\mathrm{a}}$ & 0.22 & $* *$ \\
\hline Preening \% & $6.00^{\mathrm{b}}$ & $9.80^{\mathrm{a}}$ & $10.0^{\mathrm{a}}$ & $10.13^{\mathrm{a}}$ & 0.54 & $*$ \\
\hline Pecking \% & $6.07^{\mathrm{a}}$ & $5.03^{\mathrm{a}}$ & $6.43^{\mathrm{a}}$ & $5.47^{\mathrm{a}}$ & 0.28 & N.S \\
\hline Feather pecking \% & $6.17^{\mathrm{a}}$ & $2.97^{\mathrm{b}}$ & $3.17^{\mathrm{b}}$ & $1.96^{\mathrm{c}}$ & 0.21 & $* *$ \\
\hline Aggressiveness \% & $5.43^{\mathrm{a}}$ & $2.10^{\mathrm{b}}$ & $1.60^{\mathrm{bc}}$ & $0.50^{\mathrm{c}}$ & 0.18 & $* *$ \\
\hline
\end{tabular}

T0: control (SDW; standard drinking water DW), T1: SDW+0.5 g tryptophan/1 L DW, T2: SDW+2 mg serotonin/1 L DW, T3: SW+0.5 g Optifeed®/1 L DW. Non-significant with the same superscripts. a, b,c Means within rows with different superscripts differ significantly at * $(\mathrm{P} \leq 0.05) \& * *(\mathrm{P} \leq 0.01)$.

The results in table 2 showed that there was a significant superiority in all performance characteristics for the water additive treatments for 42 days compared to the control T0. Bodyweight (BW) and weight gain (BWG), water consumption, the relative weights of liver and gizzard, uniformity \%, production index (PI), Feasibility or economic profit (EP) were significantly $(\mathrm{p}<0.01)$ higher in the treatments $\mathrm{T} 3, \mathrm{~T} 2$ and $\mathrm{T} 1$, also feed conversion ratio (FCR) significantly $(\mathrm{p}<0.01)$ improved in $\mathrm{T} 3, \mathrm{~T} 2$, and $\mathrm{T} 1$, similarly feed intake was significantly $(\mathrm{p}<0.05)$ increased in $\mathrm{T} 3$ and $\mathrm{T} 2$ compared with $\mathrm{T} 1$ and $\mathrm{T} 0$. However, the mortality percentage was significantly $(\mathrm{P}<0.01)$ lower in $\mathrm{T} 2$, and $\mathrm{T} 3$ and $\mathrm{T} 1$.

Optifeed ${ }^{\circledR}$ acting as appetite stimulants through their effect on the appetite center in the brain via the olfactory axis and pharyngeal to stimulate birds to eat feed (Fode, 2013) resulting in an increasing in the amount of feed consumed, which reflects the increase in weekly BWG and final BW, FCR improvement for all added the treatments (Mustafa et al., 2017). Because thus lead to more serotonin secretion and chicken perform better performance. Also, tryptophan which is found in foods participates in forming serotonin 
(Natalie, 2018). Best et al., (2010) refers to serotonin as a neurotransmitter it linked to a wide variety of behaviors regulation. Mustafa et al, (2019) showed the dietary additive of Optifeed increased performance characteristics during the finisher period, may enhance and regulate eating behavior, as a result of serotonin secretion in the hypothalamus, because serotonin in the brain can affect mood, eating feed, healthful, balanced diet is an essential way to support mental as well as physical health (Natalie, 2018). While a reduction in bird mortality for the Optifeed supplemented groups were observed during the rearing periods. This suggests a positive effect of it on amino acid absorption and balance in the body starter and grower diets (Brzóska et al, 2015). More serotonin secretion has more importance in all body functions a feeling of happiness and good welfare lower mortality rate better economic profits. Even if broiler diets were formulated based on other amino acids to yield suboptimal performance, it may be beneficial to provide the diet with an optimal amount of tryptophan to improve the body performance of treated birds (Opoola et al., 2017).

Table (2): The impact of adding tryptophan, serotonin and Optifeed ${ }^{\circledR}$ in drinking water on broiler body performance.

\begin{tabular}{|c|c|c|c|c|c|c|}
\hline Traits & T0 & T1 & T2 & T3 & MSE & S.L \\
\hline BW(g) & $2700^{\mathrm{c}}$ & $2860^{\mathrm{b}}$ & $2920^{\mathrm{b}}$ & $3100^{\mathrm{a}}$ & 204 & $* *$ \\
\hline BWG (g) & $2658^{\mathrm{c}}$ & $2818^{\mathrm{b}}$ & $2878^{\mathrm{b}}$ & $3058^{\mathrm{a}}$ & 189 & $* *$ \\
\hline FI (g/bird) & $4699^{\mathrm{b}}$ & $2821^{\mathrm{ab}}$ & $4918^{\mathrm{a}}$ & $5085^{\mathrm{a}}$ & 228 & $*$ \\
\hline FCR (g feed/g BW/day) & $1.778^{\mathrm{a}}$ & $1.711^{\mathrm{b}}$ & $1.709^{\mathrm{b}}$ & $1.663^{\mathrm{c}}$ & 0.12 & $* *$ \\
\hline Water consumption (ml/bird/day) & $254.7^{\mathrm{c}}$ & $270.2^{\mathrm{b}}$ & $283.3^{\mathrm{ab}}$ & $313.8^{\mathrm{a}}$ & 27.4 & $* *$ \\
\hline Mortality \% & $8.0^{\mathrm{a}}$ & $4.0^{\mathrm{b}}$ & $2.0^{\mathrm{c}}$ & $2.0^{\mathrm{c}}$ & 0.25 & $* *$ \\
\hline EDP \% & $70.3^{\mathrm{b}}$ & $72.6^{\mathrm{ab}}$ & $73.7^{\mathrm{ab}}$ & $75.4^{\mathrm{a}}$ & 3.11 & $*$ \\
\hline Liver \% & $2.04^{\mathrm{c}}$ & $2.45^{\mathrm{b}}$ & $2.65^{\mathrm{b}}$ & $3.18^{\mathrm{a}}$ & 0.17 & $* *$ \\
\hline Gizzard \% & $1.42^{\mathrm{c}}$ & $1.81^{\mathrm{b}}$ & $1.93^{\mathrm{ab}}$ & $2.19^{\mathrm{a}}$ & 0.11 & $* *$ \\
\hline Uniformity \% & $80.5^{\mathrm{c}}$ & $87.8^{\mathrm{b}}$ & $89.0^{\mathrm{ab}}$ & $92.6^{\mathrm{a}}$ & 3.8 & $* *$ \\
\hline PI & $332^{\mathrm{c}}$ & $382^{\mathrm{b}}$ & $398^{\mathrm{ab}}$ & $434^{\mathrm{a}}$ & 29.5 & $* *$ \\
\hline Feasibility (EP / ) & $1.02^{\mathrm{c}}$ & $1.33^{\mathrm{b}}$ & $1.58^{\mathrm{ab}}$ & $1.75^{\mathrm{a}}$ & 0.23 & $* *$ \\
\hline
\end{tabular}

T0: control (SDW; standard drinking water DW), T1: SDW+0.5 g tryptophan/1 L DW, T2: SDW+2 mg serotonin/1 L DW, T3: SW+0.5 g Optifeed®/1 L DW. BW: Body weight, BWG: Body weight Gain, FI: Feed intake, EDP: Eviscerated dressing percentage, PI: production index, Feasibility (EP: economic profit), Non-significant with the same superscripts. ${ }^{\text {a, b, c }}$ Means within rows with different superscripts differ significantly at $*(\mathrm{P} \leq 0.05) \& * *(\mathrm{P} \leq 0.01)$.

Table 3 shows the results of sensory evaluation of cocked breast and thigh meats were significantly $(\mathrm{P}<0.01)$ high aroma, taste and acceptance of breast also thigh muscles were high improvement showed in water additive Tryptophan, serotonin and Optifeed compared with control T0. Additionally, this table showed a significant $(\mathrm{P}<0.05)$ increase in tenderness and juiciness of breast and thigh meat when supplemented with drinking water compared with control without supplementation during the period 42 days of age. The release of meat aroma during cocking and its appearance on the plate influences the acceptability. Also, Resconi et al., (2013) feel the meat texture (tenderness, juiciness, etc.), 
aroma, and taste are the main factors that influence the sensory quality of the product when enters the mouth. Huff-Lonergan and Lonergan, (2005) declared that tryptophan antioxidative activity in dietary may partially increase water-holding capacity. Optifeed has a good odor which increased impacts on the breast and thigh muscles improved aroma, taste, tenderness, juiciness, and acceptance (Mustafa et al., 2019).

Table (3): The impact of adding tryptophan, serotonin and Optifeed ${ }^{\circledR}$ in drinking water on broiler meat (breast and thigh) sensory evaluation at age 42 days.

\begin{tabular}{|c|c|c|c|c|c|c|c|}
\hline \multicolumn{2}{|c|}{ Traits } & T0 & T1 & T2 & T3 & MSE & S.L \\
\hline \multirow{2}{*}{ Aroma } & breast & $4.17^{\mathrm{c}}$ & $5.40^{\mathrm{b}}$ & $5.75^{\mathrm{ab}}$ & $6.05^{\mathrm{a}}$ & 0.27 & $* *$ \\
& thigh & $4.60^{\mathrm{c}}$ & $5.75^{\mathrm{b}}$ & $5.90^{\mathrm{ab}}$ & $6.70^{\mathrm{a}}$ & 0.25 & $* *$ \\
\hline \multirow{2}{*}{ Taste } & breast & $4.33^{\mathrm{c}}$ & $5.33^{\mathrm{b}}$ & $5.33^{\mathrm{b}}$ & $5.80^{\mathrm{a}}$ & 0.18 & $* *$ \\
& thigh & $4.70^{\mathrm{c}}$ & $5.50^{\mathrm{b}}$ & $5.67^{\mathrm{ab}}$ & $6.33^{\mathrm{a}}$ & 0.23 & $* *$ \\
\hline \multirow{2}{*}{ Tenderness } & breast & $3.73^{\mathrm{b}}$ & $4.10^{\mathrm{b}}$ & $4.87^{\mathrm{ab}}$ & $5.60^{\mathrm{a}}$ & 0.19 & $*$ \\
& thigh & $4.27^{\mathrm{c}}$ & $5.00^{\mathrm{b}}$ & $5.25^{\mathrm{b}}$ & $6.11^{\mathrm{a}}$ & 0.33 & $* *$ \\
\hline \multirow{2}{*}{ Juiciness } & breast & $3.45^{\mathrm{b}}$ & $3.75^{\mathrm{b}}$ & $4.60^{\mathrm{a}}$ & $5.00^{\mathrm{a}}$ & 0.20 & $*$ \\
& thigh & $4.13^{\mathrm{c}}$ & $4.80^{\mathrm{b}}$ & $4.97^{\mathrm{b}}$ & $5.95^{\mathrm{a}}$ & 0.24 & $* *$ \\
\hline \multirow{2}{*}{ Acceptance } & breast & $4.00^{\mathrm{c}}$ & $5.15^{\mathrm{b}}$ & $5.30^{\mathrm{b}}$ & $6.00^{\mathrm{a}}$ & 0.21 & $* *$ \\
& thigh & $4.60^{\mathrm{c}}$ & $5.50^{\mathrm{b}}$ & $5.67^{\mathrm{b}}$ & $6.45^{\mathrm{a}}$ & 0.28 & $* *$ \\
\hline
\end{tabular}

T0: control (SDW; standard drinking water), T1: $\mathrm{SW}+0.5 \mathrm{~g}$ tryptophan, T2: $\mathrm{SW}+2 \mathrm{mg}$ serotonin, $\mathrm{T} 3: \mathrm{SW}+0.5 \mathrm{~g}$ Optifeed ${ }^{\circledR}$. a, b, c Means within rows with different superscripts differ significantly at *(P $\leq$ $0.05) \& * *(\mathrm{P} \leq 0.01)$.

Table 4 shows that adding of tryptophan, serotonin and Optifeed ${ }^{\circledR}$ in drinking water were significantly $(\mathrm{P}<0.01)$ increased the concentration of globulin, HDL, serotonin, thyroxin and tryptophan in blood serum in the treatments of water additive, also total protein was significantly $(\mathrm{P}<0.05)$ higher in $\mathrm{T} 1, \mathrm{~T} 2, \mathrm{~T} 3$ compared with the control. On the other hand, LDL, triglyceride, and corticosterone were significantly $(\mathrm{P}<0.01)$ decreased in the treatments of water additives compared to the control T0. Feed additives either alone or in combination has significant growth performance- enhancing effect in broiler chicks without any side effects as detected by normal physiological blood profile (Das et al., 2016). Serotonin affects many parts of the body and allows for internal chemical balance (Christine R., 2019). For triglycerides, the reason for their lack of concentration in plasma may be to the ability of substances to inhibit the process of triglyceride production in the liver (Jebur et al., 2018). While indicated significant differences in the increase of total protein, and blood plasma globulin, added to the diets compared with the treatment of control, and the increase of albumin in the blood plasma was evidence of the increased immune status of birds (Abbas et al,. 2011).Tryptophan which is required to reduce lipid level and maximize body growth of broiler (Rosa et al., 2001). linear reduction of blood plasma cholesterol with an increase of tryptophan showed by (Corzo et al., 2005). The additives also contain flavonoids and terpenoids, which are phenolic compounds within the spices and essential oils that act as adjuvants to maintain blood cells (Mohammed, 2012), the increase of T4, and corticosterone reduction secretions an evidence of it. 
Table (4): The impact of adding tryptophan, serotonin and Optifeed® in drinking water on some serum biochemical concentrations of broiler at 42 day.

\begin{tabular}{|l|c|c|c|c|c|c|}
\hline \multicolumn{1}{|c|}{ Traits } & T0 & T1 & T2 & T3 & MSE & S.L \\
\hline Total protein $(\mathrm{g} / \mathrm{dL})$ & $2.823^{\mathrm{b}}$ & $3.653^{\mathrm{a}}$ & $3.555^{\mathrm{a}}$ & $3.824^{\mathrm{a}}$ & 0.353 & $*$ \\
\hline Globulin $(\mathrm{g} / \mathrm{dL})$ & $1.434^{\mathrm{c}}$ & $2.283^{\mathrm{b}}$ & $2.141^{\mathrm{b}}$ & $2.663^{\mathrm{a}}$ & 0.221 & $* *$ \\
\hline HDL $(\mathrm{mg} / \mathrm{dL})$ & $32^{\mathrm{d}}$ & $40^{\mathrm{c}}$ & $45^{\mathrm{b}}$ & $47^{\mathrm{a}}$ & 1.73 & $* *$ \\
\hline LDL $(\mathrm{mg} / \mathrm{dL})$ & $128^{\mathrm{a}}$ & $82^{\mathrm{b}}$ & $74^{\mathrm{c}}$ & $58^{\mathrm{d}}$ & 2.62 & $* *$ \\
\hline Triglyceride $(\mathrm{mg} / \mathrm{dL})$ & $405^{\mathrm{a}}$ & $327^{\mathrm{b}}$ & $292^{\mathrm{c}}$ & $270^{\mathrm{d}}$ & 20.4 & $* *$ \\
\hline Serotonin $(\mathrm{ng} / \mathrm{ml})$ & $75.32^{\mathrm{c}}$ & $179.35^{\mathrm{b}}$ & $226.01^{\mathrm{a}}$ & $210.84^{\mathrm{ab}}$ & 4.58 & $* *$ \\
\hline Corticosterone $(\mathrm{ng} / \mathrm{ml})$ & $10.670^{\mathrm{a}}$ & $7.828^{\mathrm{b}}$ & $6.217^{\mathrm{bc}}$ & $5.619^{\mathrm{c}}$ & 0.42 & $* *$ \\
\hline Thyroxin $(\mathrm{T} 4)(\mathrm{ng} / \mathrm{ml})$ & $13.747^{\mathrm{c}}$ & $16.436^{\mathrm{b}}$ & $17.928^{\mathrm{ab}}$ & $19.156^{\mathrm{a}}$ & 1.28 & $* *$ \\
\hline Tryptophan $(\mathrm{ng} / \mathrm{ml})$ & $13.30^{\mathrm{d}}$ & $124.83^{\mathrm{a}}$ & $86.83^{\mathrm{b}}$ & $72.29^{\mathrm{c}}$ & 2.45 & $* *$ \\
\hline
\end{tabular}

T0: control (SDW; standard drinking water DW), T1: SDW+0.5 g tryptophan/1 L DW, T2: SDW+2 mg serotonin/1 L DW, T3: $\mathrm{SW}+0.5 \mathrm{~g}$ Optifeed ${ }^{\circledR} / 1 \mathrm{~L}$ DW. ${ }^{\text {a, b, c }}$ Means within rows with different superscripts differ significantly at * $(\mathrm{P} \leq 0.05) \& * *(\mathrm{P} \leq 0.01)$.

The results in table 5 explain the addition of tryptophan, serotonin and Optifeed ${ }^{\circledR}$ in broiler drinking water which had significantly $(\mathrm{P}<0.01)$ increased serum antibodies titration against Newcastle, Gamboro, and Infectious bronchitis viral diseases compared to the control T0. Also was found that $\mathrm{H} / \mathrm{L}$ ratio significantly $(\mathrm{P}<0,05)$ lower in the additive treatments compared with the control T0. All feed additive have uncommon components that provide unique health benefits by minimizing free radical and raising the antioxidant capacity of blood and improves body health of poultry that may be enhanced immune statues (Ragab et al., 2010). Dietary additive with Optifeed improved birds immune response to ND, IBD, and IBV, also improved in H/L ratio (Mustafa et al., 2017 and 2019). Serotonin is one of the important hormones which leads to increase the immunity of cells, tryptophan is the precursor of serotonin may play a role in the function of the innate immune system, by the presence of serotonin receptors that exist in leukocytes, and transporter for this amine has been found in macrophages, mononuclear leukocytes, and B cells, this neurotransmitter may be a critical element for the connection between the nervous and immune systems (Hofstetter et al., 2005). These additives have been shown to stimulate cells to secrete a substance similar to interferon, preventing viruses from attacking the cells of the body, increasing antibody production and the ability to increase macrophages by a direct effect on cytokines. Increases the fighting ability of macrophage cells and enhances the activity of $\mathrm{T}$ cells, which is responsible for cellular immunity (Mohammed, 2012).

Conclusion:. Serotonin, tryptophan, and Optifeed ${ }^{\circledR}$ addition in drinking water gave the best behavior characteristics, body performance in most measured parameters, improvement of meat qualities (breast and thigh) by sensory evaluation, more useful effects on the serum of some biochemical concentrations and serum antibodies titration against ND, IBD and IBV diseases of broiler parameters compared with control during 42 days of age. 
Table (5): The impact of adding tryptophan, serotonin and Optifeed ${ }^{\circledR}$ in broiler drinking water on broiler serum antibodies titration against ND, IBD and IBV diseases (ng/ml) by ELISA and $\mathrm{H} / \mathrm{L}$ ratio at 42 day.

\begin{tabular}{|c|c|c|c|c|c|c|}
\hline Traits & T0 & T1 & T2 & T3 & MSE & S.L \\
\hline ND & $3570^{\mathrm{c}}$ & $5442^{\mathrm{b}}$ & $6311^{\mathrm{ab}}$ & $6575^{\mathrm{a}}$ & 257 & $* *$ \\
\hline IBD & $2841^{\mathrm{c}}$ & $3936^{\mathrm{b}}$ & $4364^{\mathrm{ab}}$ & $4600^{\mathrm{a}}$ & 209 & $* *$ \\
\hline IBV & $2442^{\mathrm{c}}$ & $3774^{\mathrm{b}}$ & $3796^{\mathrm{b}}$ & $4125^{\mathrm{a}}$ & 168 & $* *$ \\
\hline H/L ratio & $0.47^{\mathrm{a}}$ & $0.34^{\mathrm{b}}$ & $0.33^{\mathrm{b}}$ & $0.27^{\mathrm{b}}$ & 0.07 & $*$ \\
\hline
\end{tabular}

T0: control (SDW; standard drinking water DW), T1: SDW+0.5 g tryptophan/1 L DW, T2: SDW+2 mg serotonin/1 L DW, T3: SW+0.5 g Optifeed®/1 L DW. ND: Newcastle disease, IBD: Gamboro disease, IBV: Infectious bronchitis viral disease $\mathrm{H} / \mathrm{L}$ : heterophil lymphocyte, ${ }^{\mathrm{a}, \mathrm{b}, \mathrm{c}}$ Means within rows with different superscripts differ significantly at $*(\mathrm{P} \leq 0.05) \& * *(\mathrm{P} \leq 0.01)$.

تأثير إضافة السيروتونينون و التربتوفان و أوبتيفيد الى ماء الثرب في سلوك فروج اللحم والأداء الإنتاجي وبعض الصفات الكيموحيوية للدم

$$
\text { محبوبة عبدالغني مصطفى }
$$

قسم الثروة الحيوانية/ كلية علوم الهندسة الزراعية/ جامعة صلاح الدين-أربيل/ العراق

Email:mahbuba.mustafa@su.edu.krd

\section{الخلاصة}

الهدف من الدراسة معرفة تأثير إضافة السيروتونين والتربتوفان واوبتبفيد في ماء الثرب على سلوك فروج اللحم (روس- 308) وأداءه الآنتاجي، التقييم الحســي للحم الصـــدر والفذذ، وصـــفات الدم الكامل وبعض الصـــفات

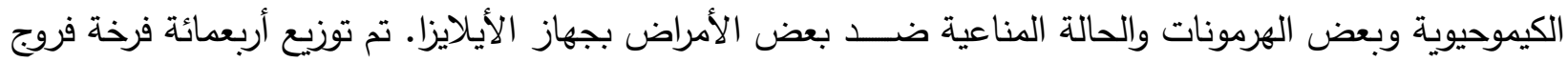

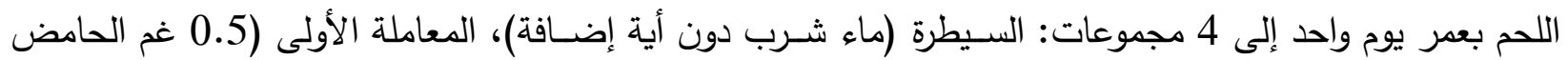
الأميني تربتوفان/لتر ماء، المعاملة الثانية (2 ملغم سـيروتونين/ لتر ماء، المعاملة الثالثة (0.5 غم اوبتيفيد/لترماء. ربيت الأفراخ لمدة 42 يوما وتم مراقبة سلوك الطير من خلال كاميرات نصبت على كل مكرر لكل معاملة. تحسنت نتائج التحليل الإحصائي معنوياً بالنسبة لسلوك الطير ، أداء الطير (وزن الجسم، الزيادة الوزنية، تتاول العلف، معامل التحويل الغذائي، استهلاك الماء، التجانس، الوزن النسبي للكبد والقانصة) الربح الاقتصـادي، التقييم الحسي (النكهة،

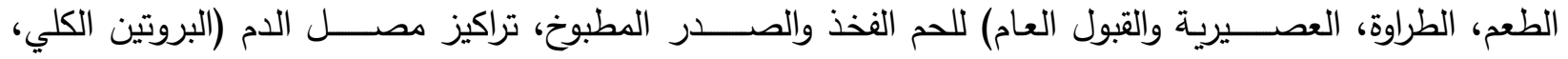
الكلوبيولين، البروتينات الدهنية عالية الكثافة، الســيروتونين، الثايروكسـين، التربتوفان وقياس مناعة الطيور بجهاز الإيلايزا (المعيار الحجمي لإضداد الدم ضد حمى النيوكاسل، الكمبورو و التهاب الثعب الهوائية)، في حين انخفض معدل الهلاكات، تراكيز مصل الدم لل (الكليسريدات الثلاثية، البروتينات الدهنية واطئة الكثافة و الكورتيكوستيرون) في معاملات الإضـافة T2، T2 و T3 مقارنة مع مجموعة السيطرة T0. دعاملتي الأوبتوفيد والسيروتونين في معطم الصفات المدروسة للدراسة مقارنة بالمعاملات الأخرى، وخاصة سلوك الطير خلال مدة التجربة. 
الكلمات المفتاحية: سلف السيروتونين، سلوك فروج اللحم، الأداء الأنتاجي، كيموحيوية الدم. تاريخ تسلم البحث: / / / 2020 ، وقبوله: / / / 2020

REFERENCES

Abbas, S.A., U.A. Khan, and A.H. Uddin. (2011). Seasonal changes effects on the serotonin and Melatonin transmission. Can J App Sci, 1(2), 01-09.

Abdoli, Alireza, C. Amy Murillo, M. Chin-Chia Yeh, C. Alec Gerry and J. Eamonn Keogh. (2018). Time Series Classification to Improve Poultry Welfare. 17th IEEE International Conference on Machine Learning and Applications (ICMLA)

Ali, A. F., T. T. Mohammed and L. K. Al-Bandar. (2019). Effect of adding different levels of Optifeed ${ }^{\circledR}$, Vêo ${ }^{\circledR}$ premium and Oleobiotec ${ }^{\circledR}$ to the diets as appetite stimulants in the production and physiological performance of male broiler under heat stress conditions. Plant Archives, 19 (1), 1491-1498.

Aliouche, H. (2018). The Relationship Between Serotonin and 5-HTP. News-Medical, https://www.news-medical.net/life-sciences/TheRelationship-Between-Serotonin -and-5-HTP.aspx.

Best, J., H. F. Nijhout and Reed, M. (2010). Serotonin synthesis, release and reuptake in terminals: a mathematical model. Theoretical Biology and Medical Modelling, 7(1), 34 .

Brzóska, F., B. Śliwiński, O. Michalik-Rutkowska and J. Śliwa. (2015). The effect of garlic (Allium sativum L.) on growth performance, mortality rate, meat and blood parameters in broilers. Annals of Animal Science, 15(4), 961-975.

Christine, R. (2019). Serotonin: Why You Need It and How to Boost Levels Natural.

Corzo, A., C.A. Fritts, M.T. Kidd and B.J. Kerr. (2005). Response of broiler chicks to essential and non-essential amino acid supplementation of low crude protein diets. Animal feed science and technology, 118(3-4), 319-327.

Das, O., S.S.Patil, H.H. Savsani, R.J. Padodara, D.D. Garg, S. Marandi and N. Barad, (2016). Effect of dietary prebiotics, probiotics and synbiotics as feed additives on blood profile and broiler performance. Int. J. Sci. Environ. Technol, (5) 35463552.

Emadi, M., K. Kaveh, F. Jahanshiri, M. Hair-Bejo, A. Ideris and A.R. Alimon. (2010). Dietary tryptophan effects on growth performance and blood parameters in broiler chicks. J. Anim. Vet. Adv. 9, 700-704.

Fernstrom, J.D. (2013). Large neutral amino acids: dietary effects on brain neurochemistry and function. Amino acids, 45(3), 419-430.

Fode. (2013). Functional Additives for Better Performance. Fode Labotaries Lushtech. France.

Hofstetter, H.H., R. Mössner, K.P. Lesch, R.A. Linker, K. Toyka, and R. Gold. (2005). Absence of reuptake of serotonin influences susceptibility to clinical autoimmune disease and neuroantigen-specific interferon-gamma production in mouse EAE. Clinical \& Experimental Immunology, 142(1), 39-44. 
Huff-Lonergan, E. and S.M. Lonergan. (2005). Mechanisms of water-holding capacity of meat: The role of postmortem biochemical and structural changes. Meat science, 71(1), 194-204.

Hugo, A., S.P.C. Els, F.H. Bothma, D.E. Witt, H.J. van der Merwe and M.D. Fair. (2009). Influence of dietary lipid sources on sensory characteristics of broiler meat. South African J. of Animal Sci.; 39:11-14.

Jebur, S., T. Mohammed and A. K. Firas. (2018). Effect of vitamin E, C and aspirin in the performance, lpid peroxidation and blood biochemistry traits of broiler in heat stress. The Eurasia Proceedings of Science, Technology, Engineering and Mathematics, (3), 145-151.

Lam, D.D., A.S. Garfield, O.J. Marston, J. Shaw and K. Heisler. (2010). Brain serotonin system in the coordination of food intake and body weight. Pharmacology Biochemistry and Behavior, 97(1), 84-91.

Mohammed, Th. T. (2012). The Effect of Adding Different Levels of Artificial Antioxidans and Natural Antioxidants in The Diet on Production and Physiological Performance in Laying Hens. (Doctoral dissertation), College of Agriculture/ Univ. of Anbar.

Mustafa, A. Mahbuba, S.P. Payam and A.M. Nizal. (2017). Effect of functional feed additives on egg production, hatchability and hematological traits of Japanese quails during summer condition. The Iraqi Journal of Agricultural Sci.(48), 80.

Mustafa, A. Mahbuba, S.Y. Sardary, A.A. al-rawi and B. Medina. (2019). Effects of Optifeed $\AA$ and oleobiotec $\AA$ on broiler performance and immunity. International Journal of Advances in Science Engineering and Technology, 7(4), 77-83.

Natalie, B., (2018). Foods That Could Boost Your Serotonin: The Serotonin Diet August 29 Healthline Editorial Team.

Opoola, E., P.A. Onimisi, S.O. Ogundipe, and G.S. Bawa. (2017). Effect of dietary tryptophan levels on growth performance of broiler chickens reared in the hot season under tropical environment. Tropical and Subtropical Agroecosystems, 20(3).

Poultry Hub, (2019). Meat Chicken (broiler) Industry. Available at: http://www. Poultry hub. org/ production/industry-structure-and-organizations/chicken-meat/

Ragab, M.S.; R.A. Magda, and G.S. Farahat. (2010). Effect of molukhyia or parsley feeding on carcass characteristics glutathione peroxidase enzyme activity and meat quality of two broiler strains. Egypt. Poult. Sci, 30:353-389.

Resconi, V.C., Escudero, A. and Campo, M.M. (2013). The development of aromas in ruminant meat. Molecules, 18(6), 6748-6781.

Rosa, A.P., G.M. Pesti, H.M. Edwards and R. Bakalli. (2001). Tryptophan requirements of different broiler genotypes. Poultry science, 80(12), 1718-1722.

SAS, Statistical analysis system. (2005). User's Guide for Personal Computer. Release 8.2 SAS Institute Inc. Cary. NC, USA.

Soh, N.L and G. Walter. (2011). Tryptophan and depression: can diet alone be the answer Acta Neuropsychiatrica, 23(1), 3-11. 
Uçeyler, N., M. Schütt, F. Palm, C. Vogel, M. Meier, A. Schmitt, (2010). Lack of the serotonin transporter in mice reduces locomotor activity and leads to genderdependent late onset obesity. Int. J. Obes. (34), 701-711.

Zendehdel, M., F. Hamidi, V. Babapour, K. Mokhtarpouriani and RMN. Fard. (2012 a). The effect of melanocortin (Mc3 and Mc4) antagonists on serotonin-induced food and water intake of broiler cockerels. Journal of veterinary science, 13(3),229234.

Zendehdel, M., M. Taati, H. Jonaidi and E. Amini. (2012 b). The role of central 5-HT 2C and NMDA receptors on LPS-induced feeding behavior in chickens. Journal of Physiological Sciences, 62(5), 413-419. 